\title{
Trade, non-state actors and conflict: evidence from Greece and Turkey
}

\author{
Dimitris Tsarouhas \\ Bilkent University \\ Nüve Yazgan \\ University of Surrey
}

\begin{abstract}
To what extent does growing trade lessen the probability of inter-state conflict? This paper addresses this question by using the curiously under-studied dyadic relationship between Greece and Turkey. Measuring trade and foreign direct investment (FDI) volumes as well as tourism flows and by use of elite interviews with key actors from both countries, we find that economic relations have become stronger and more diverse over time, non-state actors now featuring prominently in deepening interaction. Such developments, however, fail to translate into conflict resolution at the political level. To account for these findings, we use a New Liberal approach, arguing that this helps us explain both enhanced plurality in bilateral economic exchange and the incompatibility of the two countries' respective conceptions regarding legitimate national borders.
\end{abstract}

\section{Introduction}

The literature on economic interdependence and conflict is dynamic and evolving. Some argue that trade flows are determined by the intensity of inter-state relationships and that close relations lead to higher levels of interaction (Morrow et al 1998), while others stress that conflict has disruptive effects on trade relations (Polachek and McDonald 1992). A slightly different debate concerns the effects of trade interdependence on the possibility of conflict, Oneal and Russett (1999) demonstrating the pacific effects of trade interdependence on conflict and the negligible effects of trade asymmetries on conflict probability. Kastner (2009) demonstrates the constraining effect of trade interdependence on conflict, since the latter could be harmful to domestic social groups, but Keshk et al (2004), using the Militarized Interstate Disputes (MID) data, argue that politics remains supreme and the liberal argument on the trade-conflict relationship is wrong. More recently, Dale Copeland (2014) has formulated a dynamic theory that stresses how future expectations of leaders regarding the future trade environment will impact on leaders' calculations re the possibility of triggering a crisis.

This paper seeks to contribute to the debate on the pacific effects of growing economic relations and the possibility of conflict. It uses the case study of 
Greek-Turkish relations and argues that core assumptions underpinning trade-conflict approaches and ideational liberalism capture the essence of the dynamics that dominate this dyadic relationship. Commercial and ideational variants of liberal international relations (IR) are clearly not always in sync, but the paper demonstrates under which circumstances Moravcsik's 'New Liberalism' can capture the complexity of modern state interaction.

The Greek-Turkish relationship is ripe for close examination and a suitable case study. North Atlantic Treaty Organization (NATO) members with a rich history of conflict, the two states are strategically located in the Eastern Mediterranean. Although bilateral economic interaction had been dormant for decades, recent years have seen dramatic change. There has been a sharp increase in interaction and exchange between the two countries and their peoples; non-state actors are now as present as politicians and military figures when distinct aspects of their bilateral relationship are examined. Yet, longstanding political problems, chief among them the Aegean dispute, minority issues and the Cyprus conflict, remain unresolved. Although the frequency of bilateral political contacts has kept pace with developing economic relations, substantial progress in resolving long-standing political disputes remains elusive. What is more, statements by senior political figures immediately considered 'provocative' by the other side continue to be regularly aired (Kathimerini, 2016a; Hürriyet Daily News, 2017). These developments provide fertile ground to examine the two countries' relations since we attempt to capture the complexity of their relation.

To clarify our use of concepts, when referring to 'non-state actors' we mean non-traditional foreign policy actors. These encompass civil society, local actors (for example mayors) and the business elite (investors and associations). Using insights from conflict-trade interdependence approaches as well as ideational liberalism, we argue that improving economic interactions can coexist with 'frozen' political relations and an inability to overcome long-standing political differences. This results from the 'mixed preferences' characterizing the set of outcomes Greece and Turkey strive for. Concretely, we argue that the post1999 rapprochement and increasing economic ties have led to more coordination and information exchange to avoid fatal accidents and the possibility of conflict but have not changed the expected distribution of benefits to be derived from full-fledged political dialogue. Secondly, and equally importantly, the expectation of a 'spill-over' effect from growing economic ties to political bonds is not consistent with ideational liberalism, to the extent that national conceptions of legitimate borders are incompatible, and powerful social groups in both states contribute to a zero-sum game on that issue.

In what follows, we begin with a review of the literature on Greek-Turkish relations and add a brief note on our methodological approach. We then proceed to explain our theoretical standpoint, before providing a brief overview of the current state of Greek-Turkish relations. The following section demonstrates our empirical data by examining cross-border trade, FDI volumes and tourism flows. ${ }^{1}$ The next part then links those outcomes to bilateral political

\footnotetext{
${ }^{1}$ We deliberately excluded the energy field from our analysis as this mostly concerns hard security issues as well as geopolitics. It also involves a variety of international actors which are beyond the scope of this study.
} 
problems and applies our theoretical framework to explain the observed outcomes, while the conclusion summarizes the main argument.

\section{Greek-Turkish relations: an inconclusive literature}

Most studies on Greek-Turkish relations emphasize bilateral political conflict over the Aegean Sea and the Cyprus issue (Aydin and Ifantis 2004; Bahcheli 1990; Couloumbis and Ifantis 2002; Ifantis 2005). Considering bilateral developments over the last decades, far too little attention has been paid to the potential impact of increasing economic ties between the two countries. The recent, yet important, changing dynamics that are giving shape to contemporary Greek-Turkish relations have often been understudied, despite their consequences for the overall shape of this crucial bilateral relationship in a volatile region.

In recent years, a literature on non-state actors pertaining to Greek-Turkish relations has certainly emerged, interpreting the two states' relations through the prism of globalization, foreign policy, Europeanization and the 1999 rapprochement process. A particularly fruitful avenue of research was the role of the European Union (EU) (Rumelili 2007; Öniş and Yilmaz, 2008). Yet the salience of this literature is questionable given that the EU's ability to act as an anchor in Turkish politics has diminished greatly. Others have examined the role of civil society in bringing the two societies closer (Karakatsanis 2014; Cuhadar et al 2015). Finally, bilateral economic interactions of recent years have heightened the need to adopt a political economy approach (Papadopoulos 2008; Kutlay 2009; Tsarouhas 2009).

Papadopoulos (2008) argues that economic relations alone are not likely to change the two states' foreign policies and claims that economic relations would be more useful if they could develop in parallel with Turkey's EU accession process, a prospect that is now redundant. Tsarouhas (2009) adopts a version of interdependence theory and examines Greek-Turkish relations, finding that compared with the pre-1999 era the likelihood of military conflict has decreased and non-state actors can play a more active role in bilateral relations. However, his use of institutionalist IR to explain findings anticipated further improvement in bilateral politics ties, which have not materialized.

These studies highlight the significance of economic interactions but remain at an overtly general level of analysis by not breaking down economic interactions into discrete categories and identifying the dynamics behind them. Moreover, events over the last few years have added new complexities and necessitate a fresh look at recent data, not least in the context of the Greek economic crisis and the diminishing impact of the EU as an 'external anchor' in tying Turkish foreign policy priorities to those anticipated by Greece until recently.

One of the most important challenges to realist and institutionalist accounts has come from those scholars who adopt, implicitly or explicitly, a constructivist framework. Drawing from a variety of sources and from the point of view of political history or nationalism studies, they contend that the crux of the problem in Greek-Turkish relations is persistent mutual distrust cultivated through practices associated with the demonization of the 'other' and an educational curriculum that reinforces national stereotypes at the expense of facts- 
based dialogue (Volkan and Itzkowitz 1994; Millas 2009). This thesis has a lot of merit, and anyone familiar with the school curricula of the two states would hardly find evidence to the contrary. We argue, however, that combining trade-conflict interdependence approaches and ideational liberal insights can both engage with the specific economic dynamics of the two countries' relationship and at the same time apply a rationalist framework of analysis that incorporates ideational elements to explain state behaviour. This, we argue, is true in our case study but could potentially be applicable to other dyadic relations between states, whether one endorses the critique against mainstream constructivism's adaptation of liberal tools (Sterling-Folker 2000). Simply put, our contribution seeks to demonstrate that the failure to match improving economic relations with the resolution of bilateral political problems can be adequately accounted for from a liberal IR framework linking state-society relations, state preferences and foreign policy behaviour.

\section{A note on methodology}

Our paper draws on the most recently available statistical data and 11 elite interviews with policy officers, economic actors and civil society representatives. Data were mainly collected from the International Monetary Fund (IMF), Bank of Greece and Turkish Statistical Institute (TUIK). Interviews were conducted in 2015 and 2016 in both Greece and Turkey using a semi-structured questionnaire design. Interviewees were asked related questions based on their background and sector. Interviews were cross-referenced and integrated with our secondary resources.

\section{Theoretical framework}

\section{Economic relations as a pacifier}

The possibility of peace and prosperity in the international system has been central to liberalism. While liberals claim that democracy, free trade and international organizations provide pathways to international peace, they often disagree about the factors leading to it, or how progress can be realized (Walker and Rousseau 2016). Liberalism has been studied and discussed extensively, especially in the context of the 'Neo-Neo' debate (Jervis 1999) and is sometimes said to be so pervasive that it has become self-evident (Snyder 2004). One of the reasons behind this may be that key features of the international system have changed rapidly since the end of the Cold War. In particular, increasing interdependence between states poses major challenges to traditional understandings of foreign policy-making. Inter-state relations are now more 'pluralistic, complex and fragmented' (Moravcsik 2009, 245).

Liberals assume that state behaviour is not a priori given, but changes in relation to how state preferences are intertwined. Being inactive in foreign policy, indeed isolated, can be a perfectly rational strategy to the extent that there is no interdependence among state objectives and the latter can be satisfied through an autarchic existence. This is, of course, a rather theoretical possibility given globalization and externalities in state behaviour but it underlines the liberal logic. What matters for liberals is the set of underlying preferences that 
states have (Moravcsik 1997; Moravcsik and Schimmelfennig 2009), as it treats the distribution of interests as a systemic feature of international politics. The reason why interdependence is so vitally important, then, is down to the fact that state preferences are, often, asymmetrically distributed.

Divergent state preferences leave room for three distinct possibilities in inter-state interaction and behaviour. First is a zero-sum game (akin to realism), whereby dominant social groups in state A attempt to realize their preferences at the expense of equivalent groups in state B. State bargaining becomes difficult to achieve and the possibility of conflict is real. Second is the case of harmonious preferences, in which state A's unilateral preferences meet with little or no objections from state $B$, leading to few negative externalities. As a result, the two states' cooperation, or at least their peaceful coexistence, becomes the likeliest outcome. The third and final scenario is when two states have mixed preferences. In that scenario, states A and B stand to gain by coordinating their behaviour to realize gains (or avoid losses, such as in the case of military conflict), yet cannot agree on the distribution of benefits (Moravcsik 2010, 6). When mixed preferences are in play, states are likely to take steps towards cooperation to avoid loss-incurring incidents through policy coordination and/ or information exchange. They will, however, stop short of enhanced cooperation, as their preferences will tend not to be harmonious.

Liberal research has extensively dealt with how states' economic interactions impact on state behaviour and foreign policy preferences. To date there is little agreement as to whether economic ties lead to less conflict. Commercial liberalism stresses how a globalized economic environment incentivizes transnational economic exchange and therefore alters cost-benefit calculations. As commercial ties increase, it is likely that the use of coercive means in foreign and economic policy-making will decrease (Moravcsik 1997, 528-530). This leads to the incorporation of market incentives in states' calculations regarding the conduct of foreign economic and security policy. The simplest possible cost-benefit analysis then is that war would be highly damaging and should therefore be avoided (Moravcsik 2010, 8-9). However, what matters most is the set of incentives of powerful social groups and the distributional consequences of their preferences: governments may still resist open trade and FDI flows if the incentives for such policies among powerful groups are minimal and the costs for society visible and immediate. Important as it is, commercial liberalism's emphasis on realizing material interests is not always at ease with another major strand of liberalism discussed in below sections, namely ideational liberalism.

\section{Conflict-trade interdependence approaches}

This 'peace through trade' approach has led to a fruitful debate between realist and liberal scholars. Conflict-trade interdependence studies produce contradictory findings regarding the effect of economic ties (mainly trade flows) on peace and international conflict. 'Interdependence' implies a mutual relationship, referring to 'situations characterized by reciprocal effects among countries or among actors in different countries' (Keohane and Nye 1977, 7). Countries can be considered interdependent (1) if economic conditions in one country have influence on others and (2) if it is costly for countries to give up the 
relationship (Mansfield and Pollins 2003, 11). While the first implies sensitivity interdependence, the second relates to vulnerability interdependence (Baldwin 1980). Economic interdependence has been generally measured by trade indicators (Mansfield and Pollins 2001, 847). In our case study, the level of economic interdependence remains low and should instead be analysed in the context of interconnectedness (Keohane and Nye 1977, 7-8).

Generally, these studies have employed quantitative methods to analyse whether trade fosters peace (Polachek 1992) and/or whether economic interdependence decreases the likelihood of conflict/war (Barbieri 1996; Copeland 1996; Gelpi and Grieco 2008; Mansfield and Pollins 2003; Oneal et al 1996). Realists have remained sceptical regarding trade's impact on high politics, focusing on trade's potential to increase conflict due to unequal benefits (Waltz, 1970; Barbieri 1996; Barbieri and Levy 1999). Other scholars, however, have confirmed liberal assumptions on the existence of a negative correlation between economic interdependence and the use of military force (Mansfield 1994; Oneal et al 1996; Oneal and Russett 1997; Russett et al 1998; McDonald 2004).

Most of those studies examined dyadic effects of interdependence on conflict (Maoz 2009, 224) and measured this with level of trade flows (Mansfield and Pollins 2001, 847). Polachek's expected utility model of trade and conflict examines how leaders make cost and benefit calculations that shape trade and conflict. When there are welfare gains to be calculated, trade has a substantial impact on decreasing conflict (Polachek 1992). Economic interactions are assumed to foster communication between actors-private and governmental—which may increase cooperative relations (Mansfield and Pollins 2003, 3). Business interests play a vital role here as they lobby for pacific ties. Economic linkages with increasing contacts can also help promote communication across societies towards a cosmopolitan identity by breaking down barriers associated with national identities (Doyle 1997).

Several analysts have defined conditions determining whether economic interdependence promotes peace or conflict. Gelpi and Grieco $(2003 ; 2008)$ put forward a regime-type approach, arguing that trade relations between democracies will be prone to peaceful orientation, but trade dependence does not constraint the conflict behaviour of autocratic leaders (Gelpi and Grieco 2008, 31). McDonald (2004) focuses on free trade by borrowing insights from standard trade theory and stresses that only certain types of trade can prevent conflict behaviour, whereas trade protectionism increases the likelihood of conflict. In a similar vein, Peterson and Thies (2012) examine the commodity composition of bilateral trade by focusing on the relationship between interindustry trade and dyadic peace. They argue that it is important to look into trade composition, as independence itself cannot be meaningful, especially in the current conditions of global political economy. By calling for a renovation of trade-conflict approaches rooted in nineteenth-century conceptions of trade's political effects, they have suggested a linkage between higher levels of inter-industry trade and lower levels of dyadic militarized conflict (Thies and Peterson 2015).

Mansfield and Pevehouse $(2000,801)$ stress the institutional context within which trade is practised. The impact of trade, they argue, is conditional on the presence of trading institutions (for example regional pacts and institutions). 
The absence of the latter leads to a scenario in which trade has little influence on hostilities. Some studies also show that the outbreak of conflict is less likely between members of the same preferential trade arrangements (PTAs) (Mansfield and Pevehouse 2000). Copeland $(1996,24)$ proposes a 'trade expectations theory', suggesting that a state may choose to go to war if there is a 'high dependence and pessimistic expectations for future trade, creating a low or negative expected value for trade'. Several studies have engaged with the domestic origins of trade which impact on trade-conflict dynamics. Kleinberg and Fordham (2010, 708-710) argue that the conflict-decreasing potential of economic ties depends on economic actors engaging with trade across borders. They suggest that economic ties can shape those actors' foreign policy attitudes in line with the liberal argument. Similarly, economic interests deriving from trade interactions can have influence on domestic policy-makers in shaping the foreign-policy-making process (Fordham and Kleinberg 2011). On the other hand, Mansfield and Mutz (2009) highlight factors associated with a country's trade attitudes. They demonstrate a correlation between domestic perceptions of a country's trade partners as well as trade's impact on the domestic economy and trade perceptions. Likewise, Mutz and Kim (2017) claim to bridge the gap between economic theory and public psychology by focusing on how domestic traits, such as in-group favouritism, may potentially impact on a country's trade attitudes.

The literature discussed in the sections above is extremely useful and insightful, not least in emphasizing institutions and expectations as key variables determining state behaviour. However, it suffers from two drawbacks relevant to our purposes. First, these studies consider interdependence as synonymous with trade relations. They generally account for bilateral trade but do not measure FDI and/or tourism-related data. This limited conceptualization of economic interactions can be restrictive. Second, those studies mostly explain the role of pre-existing economic interactions but do not analyse how economic interactions can promote peaceful resolution between former enemies or societies that have experienced antagonistic relations (Press-Barnathan 2006). This is significant for our case study, given the diachronically antagonistic relations between Greece and Turkey despite their joint NATO membership and their joint membership in a PTA regime after Turkey joined the Customs Union (CU) with the EU. We argue that insights from ideational liberalism can help us, account for circumstances under which expanding economic relations lead to political normalization but fail to translate into conflict resolution. This they do by shifting the emphasis away from material interests and towards identity concerns instead.

\section{Ideational liberalism}

Ideational liberalism argues that state preferences are derived from social identities and values, that is, from 'the set of preferences held by various individuals and groups in society concerning the proper scope and nature of legitimate state objectives' (Moravcsik 2010, 7). The way that state objectives are legitimized by society will have an immediate effect on state policy, including foreign policy (Holsti 1991). That is because national conceptions of state borders (and their legitimate reach) and national identity are crucial for social groups 
that offer legitimacy to governments representing them in foreign policy. Whenever social identities and the subsequent conceptions of borders and national identity of two states are incompatible with one another, generating negative externalities, they are likely to lead to tension, making peaceful coexistence difficult. Given how crucial such conceptions are for state legitimacy and action, a zero-sum game is likely to emerge, and this will in turn lead to an invisible ceiling in the potential for conflict resolution. The logic upon which this strand of liberalism operates is very different from that of commercial liberalism, denoting both the pluralism inherent in the theory as well as the tensions that underpin its prescriptive and analytical dimensions.

\section{The evolution of Greek-Turkish relations in recent years}

Historically, Greece and Turkey have had minimal economic exchange, and interactions between non-state actors have been minimal. During the Cold War, their relations were mostly tense, despite the fact that both had been NATO members since 1952. Differences over minorities, the Cyprus conflict and border demarcation in the Aegean hindered channels of contact. Until the late 1990s, bilateral tensions impeded economic relations too. In the post-Cold War period, however, both experienced a period of Europeanization. Whereas change in Greek foreign policy orientation was realized in the second half of the 1990s, Turkish foreign policy underwent changes in the early 2000s. Successive Greek arguments supported the view that stable relations with Turkey would be feasible in the context of European integration (Tsakonas 2010, 60). Economides (2005, 481-482) argues that the Europeanization of Greek foreign policy included a period of Westernization and modernization, manifested through Greece's lifting of its veto over Turkey's membership in 1999 and its earlier veto lifting on the EU-Turkey CU). Greece, therefore, sought to link Turkish-Greek conflicts over the Aegean and Cyprus to Turkey's accession to the EU (Tzimitras 2009, 243-244). Turkish foreign policy also experienced a period of Europeanization in the early 2000s, since EU conditionality paved the way for significant changes in Turkish foreign-policy-making.

The year 1999 was a turning point for Greek-Turkish relations, marking the point in time when bilateral relations improved markedly (Ker-Lindsay 2007; Ifantis and Triantaphyllou 2015). Relations were highly tumultuous in the 1990s because of the 1996 Imia/Kardak episode, the 1997 S-300 missiles controversy and the 1999 Öcalan crisis. Six weeks after the Öcalan crisis, Foreign Ministers Papandreou and Cem took steps towards normalization. Powerful earthquakes hit Izmit and Athens in the same year, facilitating the cooperation of people and civil society organizations in rescue efforts. Through the 1999 rapprochement, the two countries signed various bilateral agreements which, inter alia, increased the volume of economic interaction. The rapid growth of the Turkish economy after the 2001 crisis combined with the EU reform process also contributed to increased economic interactions during the 2000s. However, while economic ties between the two countries have continued to expand, in the 2010s bilateral political relations started a slow yet real deterioration which may turn back the clock to the pre-rapprochement era. 


\section{Greek-Turkish economic relations: an assessment}

\section{Bilateral trade}

Bilateral trade volumes remained miniscule until the late 1990s, despite the two nations' geographic proximity. After the rapprochement period began, bilateral trade volumes reached more than US\$1 million in 2003 for the first time. Greek and Turkish political elites actively supported the increase, yet that was not enough to expand economic relations. Administrative and bureaucratic adjustments were necessary for the trend to continue. The 2003 agreement on preventing double taxation revealed mutual willingness to overcome technical obstacles (Tsarouhas 2009, 46). The volume of bilateral trade has expanded momentously as a result, reaching US\$3,413.370 billion in 2008. In 2013, it reached $\$ 5,643$.463billion, the highest ever recorded.

In 2012-2014 Turkey was Greece's primary export partner despite being a non-EU country. ${ }^{2}$ According to 2014 data, Turkey's share was 12.16 per cent of total Greek exports, the highest percentage ever recorded. In the context of Greece's economic crisis and Turkey's rising purchasing power, geographic proximity allowed for rapid trade expansion. Turkey certainly presents a significant export market for Greek products . Further, since Turkey is the less dependent party in this relationship, it could, in a conflict scenario, utilize its political resources accordingly. Yet the trade pattern between the two is not characterized by high interdependence in the sense that costs associated with its evolution remain low. Greek-Turkish bilateral trade has benefited both sides. Our interviewees point out the need for further development as well as investments between the two countries. ${ }^{3}$ Importantly, negative competition on trade has not been practised. ${ }^{4}$ This may be linked to product specialization, to which we turn next.

Greek exports mainly consist of manufactured products (32.9 per cent in 2014) and fuels and mining products (45.6 per cent in 2014). ${ }^{5}$ Refined petroleum products for the most parts are not produced but processed in Greece, before being exported to Turkey. The lack of diversity in Greek exports can be problematic, making the country vulnerable to external economic conditions, such as global price fluctuations (Papadopoulos 2008, 14-15). Following the 1996 EU-Turkey CU agreement, Turkey eliminated tariffs on manufactured products that are imported from the EU, which paved the way for a significant increase. The CU agreement has had positive impacts on the increase in both Turkish exports and imports (Neyapti, Taşkın and Üngör 2007), underscoring the role of institutions and agreements in boosting trade ties, albeit indirectly. Yet it was an incomplete CU not covering agricultural products and services, which is why Turkey is currently pushing for CU modernization (Vesterbye and Akman 2017). Turkey's exports to Greece have been diverse: fuels, chemicals, plastic and rubber, textiles and clothing, stone and glass, metals and machinery are exported. In 2015, the volume of trade between the two countries dropped to US $\$ 2.9$ billion. This resulted from the imposition of Greek capital controls as well as a decrease in world oil prices. While Turkish imports from

\footnotetext{
2 IMF Data

${ }^{3}$ Interview 4 and 9

${ }^{4}$ Interview 8

${ }^{5}$ See $<$ https://www.wto.org/english/res_e/statis_e/statis_e.htm>, accessed 4 May 2016
} 
Table 1. Turkish bilateral trade with Greece, in selected years (US\$)

\begin{tabular}{ccccc}
\hline Year & Import from Greece & Export to Greece & Balance of Trade & Volume of trade \\
\hline 1998 & 319,751 & 370,039 & 50,288 & 680,790 \\
2000 & 430,813 & 437,725 & 6,912 & 868,538 \\
2002 & 312,462 & 590,382 & 277,920 & 902,844 \\
2004 & 594,351 & $1,171,203$ & 576,852 & 765,554 \\
2006 & $1,045,328$ & $1,602,590$ & 557,262 & $2,647,918$ \\
2008 & $1,150,715$ & $2,429,968$ & $1,279,253$ & $3,413,370$ \\
2010 & $1,541,600$ & $1,455,678$ & $-85,922$ & $2,997,278$ \\
2012 & $3,539,869$ & $1,401,401$ & $-2,138,468$ & $4,941,270$ \\
2014 & $4,043,839$ & $1,539,658$ & $-2,504,181$ & $5,583,497$ \\
2015 & $1,731,340$ & $1,261,729$ & $-469,611$ & $2,993,069$ \\
2016 & $1,187,058$ & $1,427,234$ & 240,176 & $2,614,292$ \\
2017 & $1,495,306$ & $1,545,325$ & 50,019 & $3,040,631$ \\
\hline
\end{tabular}

Source: Compiled from TUIK and World Bank statistics. Data available online at: http://www.tuik.gov. tr/Start.do, https://wits.worldbank.org/countrystats.aspx

Greece were heavily affected, Turkish exports to Greece remained stable compared with 2014. This indicates the importance of economic stability for the evolution of trade relations: the two states currently face economic problems of differing magnitude. More importantly, the global economy may be entering a phase of protectionist barriers. The 2016 data is indicative , as Greek exports to Turkey were recorded as US $\$ 1,495,306.75$ and imports as US $\$ 1,545,325.53$ (see Table 1).

\section{Foreign direct investment}

Foreign direct investment flows and stocks have traditionally been low, yet elites from both sides have long declared their wish to increase mutual investment flows. Apart from several big investment deals, FDI between Greece and Turkey is composed of small and medium-sized investments ranging from manufacturing and retail to tourism. Until 2006, mutual investment flows hardly existed. In the post2006 period and in parallel with an increase in FDI in Turkey, Turkey has attracted substantial Greek investment. Greek FDI to Turkey reached $€ 2.3$ billion in 2006 and $€ 1.9$ billion in 2007. However, and as seen in Table 3, such large flows during that period were circumstantial and therefore exceptional to the overall trend of low FDI inflows to Turkey from Greece.

The acquisition of Finansbank by the National Bank of Greece (NBG) was the main reason for the dramatic increase in 2006 and 2007. The NBG investment was highly important for Greek-Turkish FDI flows for several reasons. The acquisition proved NGB's confidence in the Turkish market (Tsarouhas $2009,47)$ and was generally welcomed, despite some acrimony among domestic actors in both countries. Similarly, the Greek Eurobank EFG acquired 70 per cent of the Turkish Tekfen Bank in 2006. Institutions feature prominently again here: banking acquisitions displayed a trust in Turkey's adjustments in regulating its financial sector in the post-2001 period. ${ }^{6}$ Greek Alpha Bank and

\footnotetext{
${ }^{6}$ In 2012 Eurobank EFG left the Turkish market by selling Eurobank Tekfen to Burgan Bank of Kuwait. See http://www.tekfen.com.tr/haber_arsivi.asp?p=2013\&h=2, accessed 2 April 2016. Similarly in 2016, NGB agreed with the Qatar National Bank to sell Finansbank. See <http://
} 
Table 2. Greece's exports partners, 2014 (US\$ million)

\begin{tabular}{lll}
\hline & Greek Exports To & \\
\hline 1 & Turkey & $4,336.67$ \\
2 & Italy & $3,305.89$ \\
3 & Germany & $2,385.54$ \\
4 & Bulgaria & $1,873.72$ \\
5 & Cyprus & $1,775.37$ \\
\hline
\end{tabular}

Source: Compiled based on IMF Data, 2016, available online at: http://data.imf.org/?sk =388DFA601D26-4ADE-B505-A05A558D9A42\&ss =1469115547122

Table 3. Greek FDI flows to Turkey (€ million)

* Provisional data

Source: 'Residents' direct investment abroad by country of destination: annual data', Bank of Greece Statistics, 2016, available online at: http://www.bankofgreece.gr/Pages/en/Statistics/externalsector/ balance/transactions.aspx\#prime,

Table 4. Turkish FDI flows to Greece (€ million)

\begin{tabular}{lr}
\hline 2003 & -0.1 \\
2004 & -0.5 \\
2005 & -0.3 \\
2006 & 0.0 \\
2007 & -0.9 \\
2008 & 1.2 \\
2009 & -0.2 \\
2010 & -0.5 \\
2011 & -0.7 \\
2012 & $2-5$ \\
2013 & 12.5 \\
2014 & 5.7 \\
2015 & -1.3 \\
$2016^{*}$ & 4.0 \\
\hline
\end{tabular}

* Provisional data.

Note: A minus sign means a decrease in net direct investment.

Source: 'Non-residents' direct investment in Greece by country of origin: annual data', Bank of Greece Statistics, 2016, available online at: http://www.bankofgreece.gr/Pages/en/Statistics/default.aspx 
Turkey's Anadolu group agreed to acquire a 50 per cent stake each and the deal included Alpha Bank's ownership of Alternatifbank. However, the Turkish Banking Regulation and Supervision Agency (BDDK) blocked the sale. National concerns were revealed as the reason behind the blocking of the deal when unidentified sources in the BDDK mentioned issues such as 'national integrity and security concerns' (Radikal, 2007). Although such reactions are not unusual in media outlets, it is not common for the BDDK to block deals by suggesting a threat to national interests. This demonstrates the residue of distrust between the two countries, persisting after the 1999 rapprochement. Overall, by the end of 2010, there were 439 companies with capital originating from Greece (Kontakos 2011,4). This number had reached 686 companies in 2015 and 752 companies by the end of 2017. Turkish investment levels in Greece remain low. One reason may be Greece's wider problem of attracting FDI, a systemic problem for the Greek economy. In 2005, various Turkish clothing and footwear companies entered the Greek market (Hürriyet, 2006; Kathimerini, 2012c). Within seven years, all had exited (Radikal, 2011). The reasons mostly relate to Greece's economic downturn, which squeezed profit margins (Habertürk, 2010). In 2007, the Turkish Ziraat Bank acquired approval to open two branches in Athens and Komotini, in 2008 and 2009, respectively (Radikal, 2009). In 2010 Ziraat Bank opened a new branch in Xanthi and another in Rhodes in 2011. Moreover, Greek marinas have attracted considerable Turkish investment in recent years. In 2012, Doğuş Group's D-Marin company entered the Greek market by establishing partnerships with Lamda Development and Kiriacoulis Mediterranean Cruises Shipping. ${ }^{8}$ Similarly, in 2012 Koç Group's travel unit Setur invested in the country (Kathimerini, 2012a). Doğus group's latest investment was concluded in 2016 when it acquired 33 per cent of the shares of a luxury seaside resort (Kathimerini, 2016b).

The rapid growth of the Turkish economy in the 2000s and the reform process anchored to the EU accession prospect encouraged Greek businesspeople to invest in Turkey. There are limits, however, relating to political and economic instability, high taxation and bureaucracy. ${ }^{9}$ Those issues have become more pronounced in recent years and provide tangible obstacles to Greek investment. For Turkish investors, the small size of the Greek market, difficulties with Greek public administration, a lack of investment incentives and economic instability caused by the crisis also pose major limitations. ${ }^{10}$ One interviewee points to the difficulties of opening a company in Greece due to its bureaucracy. ${ }^{11}$ In the Greek-Turkish context, the burden of administrative constraints becomes heavier when investments projects are also viewed through the prism of security considerations. ${ }^{12}$ Bilateral relations remains in the shadow of 'high politics' and is dependent upon it to foster qualitative improvement. ${ }^{13}$

www.ekathimerini.com/205182/article/ekathimerini/business/nbg-approves-finansbanksale $>$ accessed 2 April 2016.

7 Available at <http://www.tuik.gov.tr/Start.do;jsessionid=FJ21YmxFKxvnxTK01Ks9LJM bk5ChbpgZKRLvxcNMpQtg18mfJLzh!-911170988>, 28 March 2018

${ }^{8}$ D-Marin Group Brochure (personal communication, 7 October 2015)

9 Interview 4

${ }^{10}$ Interview 2

${ }^{11}$ Interview 5

12 Interview 10

${ }^{13}$ Interview 7 


\section{Tourism}

Tourism is another pillar of interactions relevant to our case study. It paves the way for wider societal interaction and can facilitate trust-building initiatives. Given the geographical proximity of the two countries, cooperation in the tourism sector has promising potential. Cooperation between the two tourism communities has been high. This can be explained by tourism's high benefit to the two economies, not least in compensating for their current account deficits and dependence on export markets to cover energy needs. Tourism enables the formation of personal contacts between societies through bridging borders and can be a win-win game for the respective industries. The two countries offer similar tourism products; increasing tourist flows between two countries and promoting joint tours for overseas tourists is thus mutually beneficial (Hürriyet Daily News 2013). Joint tour packages have long been on the agenda at both state and non-state level since the early 2000s (Milliyet, 2004). However, there have always been organizational problems. ${ }^{14}$

The number of Greek and Turkish citizens visiting each other's country has increased immensely since the 2000s. Greek visitors arriving in Turkey reached 830,841 in 2014 , up from only 218,092 in 2000. A total of 741,037 Turkish citizens visited Greece in 2014 and 898,919 in 2015 compared with a mere 170.019 in 2003. This trend can be explained both by inter-state initiatives and by business-level cooperation. Yet the number of Turkish citizens visiting Greece has been relatively smaller than the number of Greek citizens visiting Turkey due to the Schengen visa regime. Greek citizens have been able to visit Turkey without visa requirements since 1985. In 2010, Greece removed the visa requirement for citizens with Green passports, ${ }^{15}$ because the Turkish government had called for changes in visa regulations. In 2012, the Greek government initiated a special visa to be obtained upon arrival in several eastern Aegean islands during the summer period, and this scheme has continued since then. It had led to a marked rise in the flow of Turkish visitors. A significant decrease was recorded in 2016, when Greek visitors dropped to 593,150 due to terrorist attacks and the 15 July coup attempt in that year. The recovery in 2017 was quick, however (see Table 5) and Turkish visitors to Greece continued to flow in at record numbers.

Although tourism provides significant economic benefits, it also has limitations. Tourism is a typical 'buyer's market' and vulnerable to events in the host country (Papadopoulos 2008, 296). Importantly, the two countries offer alternative destinations and are thus expected to benefit from each other's woes in the event of tourism-related shocks. Some evidence of that has become evident in the aftermath of successive large-scale terrorist attacks in Turkey in recent years (Kathimerini, 2015).

Tourism cooperation has long been supported by the two countries' tourism associations and local administrations. Greek-Turkish friendship festivals and town twinning between Greek and Turkish municipalities has long been practised as a direct manifestation of citizens' diplomacy (Karakatsanis 2014,

\footnotetext{
${ }^{14}$ Interview 5

15 Green passports are given to state officials and employees as well as former ministers and parliament members.
} 
Table 5. Number of visitors

\begin{tabular}{lcc}
\hline Year & $\begin{array}{c}\text { Number of Turkish citizens } \\
\text { visiting Greece }\end{array}$ & $\begin{array}{c}\text { Number of Greek citizens } \\
\text { visiting Turkey }\end{array}$ \\
\hline 2004 & 185,422 & 491,300 \\
2006 & 241,987 & 412,819 \\
2008 & 263,048 & 572,212 \\
2010 & 428,721 & 670,297 \\
2012 & 447,908 & 669,823 \\
2014 & 741,037 & 830,841 \\
2015 & 898,919 & 755,414 \\
2016 & 785,905 & 593,150 \\
2017 & 921,262 & 623,705 \\
\hline
\end{tabular}

Source: Compiled from TUIK, data available online at: http://www.tuik.gov.tr/Start.do;jsessionid= FJ21YmxFKxvnxTK01Ks9LJMbk5ChbpgZKRLvxcNMpQtg18mfJLzh!-911170988

242). The empowerment of local actors following the 1999 rapprochement has led to a new stream of initiatives. In recent years, Izmir and Thessaloniki have become a significant example of Greek-Turkish cooperation. Thessaloniki Mayor Yiannis Boutaris and President of Izmir Chamber of Commerce Ekrem Demirtaş have been crucial actors in challenging conventional thinking, particularly regarding the depiction of the 'other' and the stereotyping this entails. An interviewee points out that there is more potential to be realized in terms of Turkish tourists visiting Thessaloniki and the investment flow in Thessaloniki's tourism sector. ${ }^{16}$ He notes that Thessaloniki has been a good, albeit minor, example of creating initiatives to bring the two societies closer in recent years. However, he points out the need for political will from the two countries to make the process sustainable: 'at the end of the day we are not the state'.

\section{Economic ties meet national identities: the 'politics ceiling' in Greek-Turkish relations}

The evolution of Greek-Turkish relations over the last 17 years demonstrates that the inter-state international environment has become more pluralistic. What used to be a classic case of inter-state conflict has been transformed into a markedly more complex relationship. Through the 1999 rapprochement process, combined with the efforts of business and other non-state actors, economic interactions have improved markedly. Improving communication and transportation channels have reduced the impact of distance, both physical and psychological. Non-state actors (business and civil society actors) have become increasingly significant, acquiring a limited degree of autonomy in agenda-setting regarding practical areas of cooperation where harmonious interests are on display and 'where interactions do not have significant costly effects' (Keohane and Nye 1977, 9). These increasing economic ties with multiple communication channels have challenged traditional analyses premised on overwhelming political tensions trumping avenues of other forms of

\footnotetext{
16 Interview 7

17 Interview 7
} 
cooperative behaviour. The Greek-Turkish Business Council meetings, tourism fairs and local meetings have been important venues for economic cooperation outside state diplomacy.

Non-state initiatives, whether failed or realized, have become important components of the two countries' relations. One example may be the (failed) joint venture initiative to establish an 'Aegean Investment Bank'. This stems from the Greek-Turkish Chamber of Commerce chaired by Panagiotis Koutsikos and Chair of İzmir Chamber of Commerce Ekrem Demirtas (Hürriyet 2006). Also, town-twinning initiatives have become widespread between Greek and Turkish municipalities to promote Greek-Turkish cooperation (Toksöz 2004, 104-105). Some examples are: Alexandroupolis and Edirne, Chios and Çeşme, Karşıyaka and Kordelio, Komotini and Yalova. Cooperation between municipalities and business organizations in İzmir and Thessaloniki is a significant example demonstrating the role of local actors. Chair of Izmir's Chamber of Commerce Demirtas has taken part in Greek-Turkish cooperation efforts since the 1990s. He has supported and given voice to projects like the Thessaloniki-Izmir ferry connection and visa facilitation for many years. In 1998 the Izmir and Mytilini Chambers of Commerce held a summit for the first time to foster economic cooperation between the Greek islands and Turkish coastal towns. ${ }^{18}$ This summit was held in later years in various places, including Bodrum, Kalamata, Kos, Marmaris and Rhodes. Those meetings have provided opportunities to demolish psychological barriers and provide an interaction platform for state and business circles. In one of those meetings, Demirtaş initiated a petition to 'stop flight of war aircrafts over the Aegean' (Usta 2012, 106), and he has continuously voiced the need for resolution in the Aegean to foster peace (Milliyet, 2010).

Equally, Thessaloniki Mayor Boutaris has been promoting Thessaloniki's multicultural past to make the city a tourism hub and revive the local economy (Kathimerini 2014). The municipality has promoted Mustafa Kemal Atatürk's house and also monuments from the Ottoman period to attract more Turkish visitors (Kathimerini, 2012b). The number of Turkish tourists visiting Thessaloniki has thus showed a marked increase. Furthermore, Mayor Boutaris was very well received by the political and economic elite in Turkey owing to his positive statements about Turks and the relations between the two peoples (Hürriyet, 2015). Boutaris paid visits to Ankara, İstanbul and İzmir along with a delegation from the municipality and in 2011 he proposed building a mosque and cemetery for Muslims (Kathimerini, 2013), as well as renaming 'Agiou Dimitriou' street in Thessaloniki as 'Kemal Atatürk' street.

Since 1999, the two countries have experienced an overall 'normal sea' of relations through a series of agreements on the economy and trade, tourism, culture and civil society cooperation. Furthermore, the erstwhile favourable conditions of the world economy, such as high liquidity in the post-9/11 era and low interest rates, provided opportunities for both Greece and Turkey to enhance their economic activity. Greek-Turkish economic relations have benefited from this trend (Kutlay 2009, 112). Both sides are now interconnected with multiple communication channels in a manner suggesting that their level

${ }^{18}$ See IZTO Midilli İş ve İnceleme Gezisi, retrieved from http://www.izto.org.tr/portals/0/ pusuladergisi/2013/haziran/midilliisgezi.pdf 
of economic interaction can hardly drop to pre-1999 levels. The profits arising from bilateral economic ties have been acknowledged by both countries as vindicating their desire to keep increasing the scope of their economic relations.

Increasing channels of contact and non-state initiatives have made a significant contribution to economic cooperation through regular meetings, projects and fairs. The High Level Cooperation Council meetings held since 2010 are an important development in this regard. The first meeting of the council was held in Athens in 2010 with the participation of approximately 200 businesspeople. In 2013 a second meeting was held in Istanbul and a third one was held in 2014 in Athens. The fourth meeting was held in March 2016 in Izmir. ${ }^{19}$ The ties between the societies in the form of business, cultural and social exchanges are promising. The difference from the recent past is palpable. Influential actors from the two societies have supported the further integration of the two societies. Non-state actors like the Hellenic Federation of Enterprises (SEV) and the Turkish Industrialists and Businessmen's Association (TÜSİAD) are in routine interaction with government officials and policy-makers. However, communication between actors-private and government-is still limited. The impact of non-state actors on political elites has mainly been discernible at the local level through suggestions and the organization of bilateral meetings. The current scope of economic relations does not allow business interests to shape the course of Greek-Turkish relations through influencing traditional foreign policy behaviour in the two countries, and political elites continue to shape the framework of relations.

These developments are crucial when we consider how close the two countries have come to conflict in the recent past. The 1976, 1987 and 1996 crises led to serious confrontation. The Imia/Kardak crisis of 1996 was the most serious of these, almost leading to open armed conflict. At that time, economic relations and civil society bonds hardly existed but events since then have changed the dynamics. In 2005, an Imia/Kardak-like incident was avoided. When Greek Foreign Minister Molyviatis was visiting Turkey, a mini-crisis over the islets emerged. The standoff ended with negotiation between the two parties and both countries withdrawing their patrol boats. Now finding themselves in a typical 'mixed preferences' situation with an altered cost-benefit analysis, the two states coordinated their behaviour to avoid a potentially fatal confrontation that would damage economic ties through information exchange. According to one interviewee, the Imia/Kardak crisis would not have occurred if economic interactions at that time had been close to today's level: 'it is not possible for soldiers to cross borders in where the money flows'. ${ }^{20}$ Although the accuracy of such a sweeping statement is doubtful, it is true that the consequences of a possible crisis have become much costlier for the two countries. Recently, tensions restarted to heat up around Imia/Kardak when a Turkish patrol boat rammed a Greek coastguard vessel near the islets. Although the incident fuelled a negative atmosphere between two sides of the Aegean, both countries eventually withdrew their vessels from the scene, avoiding military conflict (Kathimerini, 2018). Some scholars have defined this post-1999 period

\footnotetext{
${ }^{19}$ See <http://www.mfa.gov.tr/high-level-cooperation-council-meeting-between-turkey-andgreece.en.mfa $>$

${ }^{20}$ Interview 2
} 
as 'cold peace', not only because the two countries did not take serious steps to resolve their long-standing issues but also because of rising challenges in their neighbourhood in recent years (Triantaphyllou 2017; The Economist 2017). In the last decade, both Greece and Turkey have suffered from economic and political instability, including the Greek crisis, the migrants and refugees influx and the 15 July coup attempt in Turkey. These external and domestic developments have added yet another level of complexity.

Our findings suggest that economic, societal and cultural ties do not seem to have had enough influence to change the traditional orientation of government policies. In the post-1999 period, economic relations have found space to develop in relative isolation from political problems. ${ }^{21}$ In the case of Greek-Turkish relations, economic relations can improve up to the point where they hit the 'politics ceiling' and political obstacles come to the forefront. The threat perception and mistrust from both sides play a role in creating scepticism towards one another in economic and wider interactions. These then multiply the problems relating to the bureaucratic and administrative obstacles faced by economic actors. ${ }^{22}$

It is obvious, then, that outstanding political problems place a ceiling on the potential generated by economic interactions and civil society initiatives. Those problems are not difficult to explain from an ideational liberal viewpoint. The social identity of each state has been constructed and maintained for decades based on taken-for-granted assumptions regarding the legitimacy of its claims concerning national borders and the meaning of national identity (Özkirimli and Sofos 2008; Millas 2009). What makes their respective understanding and interpretation of national identity (largely) incompatible with one another is the fact that the two identities and conceptualizations of legitimacy have been constructed in antithesis to one another (Heraclides 2010). Therefore, for one to remain legitimate at societal level, and thus allow decision-makers to pursue legitimate state preferences through foreign policy, the other's identity (also expressed through foreign policy statements and actions) must be either deficient, or hypocritical, or both. This is a structural incompatibility, the overcoming of which can be facilitated through information exchange (as in the 2005 incident mentioned above) but cannot be fully overturned. In that context and given the multitude of contact points and expected gains from economic exchanges, policy-makers avoid touching on bilateral problems that would require concessions and a conciliatory attitude. These are possible and have largely been achieved, when coordination of action and information exchange are required to avoid a heated confrontation that will reverse accrued benefits.

\section{Conclusion}

From a theoretical point of view, trade-conflict approaches provide useful analytical tools in investigating both the empirical changes underway in Greek-Turkish economic relations and the reasons behind the inability to translate this to full-fledged political reconciliation and 'warm peace'. Bilateral

\footnotetext{
${ }^{21}$ Interview 6

${ }^{22}$ Interview 10
} 
relations have evolved over time in ways that would have been hard to anticipate in the past. The level of economic interaction between the two societies has increased dramatically in fields from tourism to trade, and communication channels have multiplied through the active involvement of non-state actors. Greek-Turkish relations can no longer be reduced to interactions between the two states' officials because businesspeople, local leaders, civil associations, tourists and others are now making an active contribution, often unnoticed and yet very real, in the evolution of bilateral relations.

These developments do not lead, however, to conflict resolution and we have sought to account for that finding through use of ideational liberalism. While the trade-conflict interdependence literature offers invaluable insights on the data-driven growth in bilateral economic exchange and the salience of institutions in enhancing interaction, ideational liberalism's focus on social identities and values pertaining to issues such as national borders is helpful in explaining why relations have hit a 'ceiling'. Political problems continue to set the overall framework within which this bilateral relationship should be understood because of the two states' incompatible preferences regarding their 'legitimate being' and their mutually exclusive understanding of their national borders, a crucial component of every state's identity formation. This, in turn, is likely to affect bilateral economic ties as well, to the extent that the wider international environment becomes less favourable. The failed peace negotiations on Cyprus, the migration and refugee crisis and Turkey's deadlocked EU membership prospects contribute to a political context marked by insecurity and a complex, less predictable matrix of preferences. While cooperation on issues where the expected payoff is markedly positive for both, such as on dealing with migrants and refugees, is likely to continue, the 'mixed preferences' scenario will at best keep both parties content with a minimum of coordination to avoid costly confrontation.

Empirically, and through a breakdown of our findings according to each examined sector, we record a pattern of (relatively high) trade volumes, stable FDI flows in recent years and a continuous increase (save for the exceptional year 2016) in mutual tourism flows. The lack of institutionalization in bilateral relations and the absence of a political settlement on border disputes make relations vulnerable to frequent political storms. As the institutional anchors of the past diminish in significance (multilateral open trade policies, Turkey's EU vocation) the existence of mixed preferences complicates the win-lose calculations of policy-makers and is increasingly interacting with their unstable domestic political and economic context. In recent months, a populist rhetoric has been on the rise on both sides of the Aegean, manifesting itself especially after eight Turkish soldiers fled to Greece after the 15 July coup attempt. The tense environment between the two has been augmented by Turkey's increasingly vocal presence with respect to the Aegean and Eastern Mediterranean, fuelling nationalistic sentiments in the both countries. These developments suggest the fragility of bilateral relations in the absence of warm peace.

Finally, it is important to stress that our findings constitute a plausibility probe and need to be validated through further empirical research. Similar dyadic relationships of countries prone to conflict with one another which have upped their interaction in recent decades, not least through trade, need to be examined and tested along similar lines to reach confident conclusions. 
Cases that come to mind in this regard are those of India and Pakistan, and the two Koreas (Kastner 2009).

\section{Notes on contributors}

Dimitris Tsarouhas is Associate Professor at the Department of International Relations, Bilkent University and 2018-19 Visiting Scholar at Georgetown University's BMW Center for German and European Studies. He specializes in EU-Turkey Relations, Greek-Turkish Relations, European Politics and Public Policy. His research has been published in journals such as Regulation $\mathcal{E}$ Governance, Comparative European Politics, New Political Economy, Political Studies Review, Public Administration,Social Policy $\mathcal{E}$ Administration and Southeast European and Black Sea Studies. His latest book, coedited with Owen Parker (The University of Sheffield), is entitled Crisis in the Eurozone Periphery: The Political Economies of Greece, Spain, Portugal and Ireland (London: Palgrave 2018). Email: dimitris@bilkent.edu.tr

Nüve Yazgan is a PhD Candidate at the Department of Politics, University of Surrey. Her research interests lie in Political Economy, Greek Politics, and Greek-Turkish Relations. Email: n.yazgan@surrey.ac.uk

\section{ORCID}

Dimitris Tsarouhas (D) http://orcid.org/0000-0002-3370-3867

\section{References}

Aydin, Mustafa and Kostas Ifantis (2004) Turkish-Greek relations: the security dilemma in the Aegean (London: Routledge)

Bahcheli, Tozun (1990) Greek Turkish relations since 1955 (Boulder-San Francisco: Westview Press)

Barbieri, Katherine (1996) 'Economic interdependence: A path to peace or a source of conflict?', Journal of Peace Research, 33: 1, 29-49

Barbieri, Katherine and Jack S. Levy (1999) 'Sleeping with the Enemy: The Impact of War on Trade', Journal of Peace Research, 36: 4, 463-479

Copeland, Dale C (2014) Economic Interdependence and War (Princeton, NJ: princeton University Press)

Copeland, Dale C (1996) 'Economic interdependence and war: A theory of trade expectations', International Security 20: 4, 5-41

Couloumbis, Theodore and Kostas Ifantis (2002) 'Altering the security dilemma in the Aegean: Greek strategic options and structural constraints: a realist approach', Review of International Affairs, 2: 2, 1-25

Cuhadar, Esra, Orkun G Genc and Andreas Kotelis (2015) 'A Greek-Turkish peace project: assessing the effectiveness of interactive conflict resolution', Southeast European and Black Sea Studies, 15: 4, 563-583

Doyle, Michael W (1997) Ways of war and peace: Realism, Liberalism, and Socialism (New York/London: WW Norton \& Company)

Economides, Spyros (2005) 'The Europeanisation of Greek foreign policy', West European Politics, 28: 2, 471-491

Fordham, Benjamin O. and Katja B. Kleinberg (2011) 'International trade and United States relations with China', Foreign Policy Analysis, 7: 3, 217-236. 
Gelpi, Christopher and Joseph M Grieco. (2003) 'Economic Interdependence, the Democratic State, and the Liberal Peace', in Edward D. Mansfield and Brian M. Pollins (eds) Economic Interdependence and International Conflict (Ann Arbor: University of Michigan Press)

Gelpi, Christopher and Joseph M Grieco (2008) 'Democracy, interdependence, and the sources of the liberal peace', Journal of Peace Research, 45: 3, 17-36

Habertürk (2010) 'Yunanistan bitmiş, terk edeceğim', 24 March, <http://www. haberturk.com/ekonomi/makro-ekonomi/haber/502805-yunanistan-bitmis-terkedecegim $>$, accessed 2 April 2016

Heraclides, Alexis (2010) The Greek-Turkish conflict in the Aegean: imagined enemies (New York: Palgrave Macmillan)

Holsti, Kalevi J (1991) Peace and war: armed conflicts and international order 1648-1989 (Cambridge: Cambridge University Press)

Hürriyet (2015) 'Avrupa ortağım Türkler kardeşim', 3 May, <http://www.hurriyet. com.tr/avrupa-ortagim-turkler-kardesim-28901355>, accessed 4 December 2017

Hürriyet (2006) 'Yunanistan'la ikinci banka girişimi', 6 April, <http://www.hurriyet. com.tr/yunanistanla-ikinci-banka-girisimi-4210583>, accessed 3 December 2017

Hürriyet (2000) 'Türk-Yunan kıyılarını ortak pazarlama arayışı', 29 March, <http:// www.hurriyet.com.tr/turk-yunan-kiyilarini-ortak-pazarlama-arayisi-39143325>, accessed 10 July 2016

Hürriyet Daily News (2017) 'Turkey criticises Greek FM's statements on Cyprus talks', 8 July, <http:/ / www.hurriyetdailynews.com/turkey-criticizes-greek-fms-statementson- cyprus-talks-115267>, accessed 16 October 2017

Hürriyet Daily News (2013) 'Former rivals Greece and Turkey talk business now', 20 December, <http://www.hurriyetdailynews.com/former-rivals-greece-and-turkeytalk-business-now.aspx?pageID=238\&nID $=59861 \&$ NewsCatID $=349>$, accessed 10 July 2016

Ifantis, Kostas (2005) 'Greece's Turkish dilemmas: there and back again', Southeast European and Black Sea Studies, 5: 3, 379-394

Ifantis, Kostas and Dimitrios Triantaphyllou (2015) 'National role and foreign policy: a descriptive study of Greek elites' perceptions towards Turkey', GreeSE Paper, no: 94, London School of Economics and Political Science, <http://www.lse.ac.uk/ europeanInstitute/research/hellenicObservatory/pdf/Ifantis-Triantafylloy-(PROJECTREPORT).pdf $>$, accessed 20 July 2016

Jervis, Robert (1999) 'Realism, neoliberalism, and cooperation: understanding the debate', International Security, 24: 1, 42-63

Karakatsanis, Leonidas (2014) Turkish-Greek relations: rapprochement, civil society and the politics of friendship (London, New York: Routledge)

Kastner, Scott L (2009) Political conflict and economic interdependence across the Taiwan strait and beyond (Stanford: Stanford University Press)

Kathimerini (2018) 'Greece, Turkey withdraw ships from Imia but Cyprus stalemate remains', 14 February, <http://www.ekathimerini.com/225855/article/ekathimerini/ news/greece-turkey-withdraw-ships-from-imia-but-cyprus-stalemate-remains $>$, accessed 20 April 2018

Kathimerini (2016a) 'Greece complains to NATO over Turkish submarines in Aegean', 8 October, <http://www.ekathimerini.com/212680/article/ekathimerini/news/greececomplains-to-nato-over-turkish-submarines-in-aegean > accessed 10 October 2017

Kathimerini (2016b) 'Sale of Astir Palace to Apollo Investment finally completed', 27 October, <http://www.ekathimerini.com/213230/article/ekathimerini/business/ sale-of-astir-palace-to-apollo-investment-finally-completed $>$ accessed 4 November 2016

Kathimerini (2015) 'Developments in Turkey benefit Greek cruise tourism', 7 October, <http:/ / www.ekathimerini.com/202303/article/ekathimerini/business/developments-in- turkey-benefit-greek-cruise-tourism>, accessed 2 April 2016

Kathimerini (2014) 'Mayor's efforts pay off as Turkish and Israeli visitors flock to discover their 'own' Thessaloniki', 14 September, <http://www.ekathimerini.com/ 163038/article/ekathimerini/community/mayors-efforts- pay-off-as-turkish-andisraeli-visitors-flock-to-discover-their-own-thessaloniki>, 3 December 2017 
Kathimerini (2013) 'Thessaloniki Mayor Boutaris defends mosque move', 7 April, <http://www.ekathimerini.com/150132/article/ekathimerini/news/thessalonikimayor-boutaris- defends-mosque-move $>$, accessed 10 May 2016

Kathimerini (2012a) 'Mytilene Marina auction won by Turkish group' 4 May, <http:// www.ekathimerini.com/141324/article/ekathimerini/business/mytilene-marina-auction-won-by-turkish-group $>$, accessed 4 May 2016

Kathimerini (2012b) 'City to highlight its Turkish ties', 10 August, <http://www. ekathimerini.com/143913/article/ekathimerini/life/city-to-highlight-its-turkish-ties>, accessed 3 December 2017

Kathimerini (2012c) 'Turkish clothing firms forced to return home', 14 October, <http://www.ekathimerini.com/145422/article/ekathimerini/business/turkishclothing-firms- forced-to-return-home $>$, accessed 20 October 2016

Keohane, Robert O and Joseph S Nye (1977) Power and interdependence: world politics in transition (Boston: Little, Brown)

Ker-Lindsay, James (2007) Crisis and conciliation: a year of rapproachement between Greece and Turkey (London and New York: IB Tauris)

Keshk, Omar M. G., Brian M. Pollins and Rafael Reuveny (2004) 'Trade still follows the flag: the primacy of politics in a simultaneous model of interdependence and armed conflict', The Journal of Politics, 66: 4, 1155-1179

Kleinberg, Katja B. and Benjamin O. Fordham (2010) 'Trade and foreign policy attitudes', Journal of Conflict Resolution, 54: 5, 687-714.

Kontakos, Panagiotis (2011) 'Greek direct investments in Turkey:the pas decade and the future', Unpublished conference paper

Kutlay, Mustafa (2009) 'A political economy approach to the expansion of TurkishGreek relations: interdependence or not?', Political Science Quarterly, 123: 1, 123-149

Mansfield, Edward Deering (1994) Power, trade, and war (Princeton, NJ: Princeton University Press)

Mansfield, Edward Deering and Diana C. Mutz (2009) 'Support for free trade: selfinterest, sociotropic politics, and out-group anxiety', International Organization, 63:3, $425-457$.

Mansfield, Edward Deering and Brian M Pollins (2003) 'Interdependence and conflict: An introduction' in Edward Deering Mansfield and Brian M. Pollins (eds) Economic interdependence and international conflict: new perspectives on an enduring debate (USA: University of Michigan Press), 1-28

Mansfield, Edward Deering and Brian M Pollins (2001) 'The study of interdependence and conflict: recent advances, open questions, and directions for future research', Journal of Conflict Resolution, 45: 6, 834-859

Mansfield, Edward Deering and Jon Pevehouse (2000) 'Trade blocs, trade flows, and international conflict', International Organization 54: 4, 775-808

Maoz, Zeev (2009) 'The effects of strategic and economic interdependence on international conflict across levels of analysis', American Journal of Political Science, 53: 1, 223-240

McDonald, PJ (2004) 'Peace through trade or free trade?', Journal of Conflict Resolution, 48: 4, 547-572

Millas, Herkules (2009) 'Perceptions of Conflict: Greeks and Turks in each other's mirrors' in Othon Anastasakis, Kalypso Nicolaidis and Kerem Oktem (eds) In the long shadow of Europe: Greeks and Turks in the era of postnationalism (Leiden: Brill Press)

Milliyet (2010) 'ITO: Ege'de savaş uçakları uçmasın', 10 March, <http://www.milliyet. com.tr/ito-ege-de-savas-ucaklari-ucmasin-ekonomi-1209457/>, accessed 3 December 2017

Milliyet (2004) 'Şeker diplomat'in turizm hamlesi', 14 June, <http://www.milliyet.com. $\operatorname{tr} / 2004 / 06 / 14 /$ ege/yazyoruk.html $>$, accessed 10 July 2016

Moravcsik, Andrew (2010) Liberal theories of international relations: a primer (Princeton, NJ: Princeton University Press)

Moravcsik, Andrew (2009) 'Robert Keohane: political theorist' in Helen V Milner and Andrew Moravcsik (eds) Power, interdependence and nonstate actors in world politics (Princeton: Princeton University Press), 243-263 
Moravcsik, Andrew (1997) 'Taking preferences seriously: A liberal theory of international politics', International Organization, 51: 4, 513-553

Moravcsik, Andrew and Frank Schimmelfennig (2009) 'Liberal intergovernmentalism' in Antje Wiener and Thomas Diez (eds) European integration theory (Oxford: Oxford University Press)

Morrow, James D, Randolph M Siverson and Tressa Tabares (1998) 'The political determinants of international trade: the major powers, 1907-1990', American Political Science Review 92: 3, 649-661

Mutz, Diana C. and Eunji Kim (2017) 'The impact of in-group favoritism on trade, International Organization, 71: 4, 827-850.

Neyaptı, Bilin, Fatma Taşkın and Murat Üngör (2007) 'Has European customs union agreement really affected Turkey's trade?', Applied Economics, 39: 16, 2121-2132

Özkirimli, Umut and Spyros A Sofos (2008) Tormented by History: Nationalism in Greece and Turkey (London: Hurst)

Oneal, John R and Bruce Russett (1999) 'Assessing the Liberal Peace with Alternative Specifications: Trade Still Reduces Conflict', Journal of Peace Research, 36: 4, 423-442.

Oneal, John R, Frances H Oneal, Zeev Maoz, and Bruce Russett (1996) 'The Liberal peace: interdependence, democracy, and international conflict, 1950-1985', Journal of Peace Research 33: 1, 11-28

Oneal, John R and Bruce M Russett (1997) 'The classical liberals were right: Democracy, interdependence, and conflict, 1950-1985', International Studies Quarterly, 41: 2, 267-294

Öniş, Ziya and Şuhnaz Yilmaz (2008) 'Greek-Turkish rapprochement: rhetoric or reality?', Political Science Quarterly, 123: 1, 123-149

Papadopoulos, Constantine A (2008) 'Greek-Turkish economic cooperation: guarantor of détente or hostage to politics?', South East European Studies at Oxford (SEESOX), Occasional Paper No: 8, March, <https://production.sant.ox.ac.uk/ sites/default/files/g- teconomiccooperationmar08.pdf $>$, accessed 17 June 2016

Peterson, T. M., \& Thies, C. G. (2012) 'Beyond Ricardo: The link between intra-industry trade and peace', British Journal of Political Science, 42: 4, 747-767.

Polachek, Solomon W (1992) 'Conflict and trade: An economics approach to political international interactions' in Walter Isard and Charles Anderton (eds) Economics of arms reduction and the peace process (Amsterdam, Netherlands: North Holland Elsevier), 89-120

Polachek, Solomon W and Judy McDonald (1992) 'Strategic trade and the incentive for cooperation', in Manas Chatterji and Linda Forcey (eds) Disarmament, economic conversion and peace management (New York: Praeger), 273-284

Press-Barnathan, Galia (2006) 'The neglected dimension of commercial liberalism: economic cooperation and transition to peace', Journal of Peace Research, 43: 3, 261-278

Radikal (2011) 'Türkler Yunanistan'dan kaçyor', 22 June, <http:/ / www.radikal.com.tr/ ekonomi/turkler-yunanistandan-kaciyor-1053660/> accessed 2 April 2016

Radikal (2009) 'Ziraat'in ikinci üssü Gümülcine'de açlld', 19 February, <http://www. radikal.com.tr/ekonomi/ziraatin-ikinci-ussu-gumulcinede-acildi-922389/>, accessed 2 April 2016

Radikal (2007) 'BDDK'dan Alpha Bank-Abank evliliğine kırmızı kart güvenlik gerekçesiyle çıtı', 10 August, <http://www.radikal.com.tr/ekonomi/bddkdanalpha-bank-abank- evliligine-kirmizi-kart-guvenlik-gerekcesiyle-cikti-822408/> accessed 10 September 2016

Reus-Smit, Christian (2001) 'The strange death of liberal international theory', European Journal of International Law, 12: 3, 573-594

Rumelili, Bahar (2007) 'Transforming conflicts on EU Borders: the case of GreekTurkish relations', Journal of Common Market Studies, 45: 1, 105-126

Russett, Bruce, John Oneal, and David R. Davis (1998) 'The third leg of the Kantian tripod for peace: International organizations and militarized disputes, 1950-1985', International Organization, 52: 3, 441-467

Snyder, Jack (2004) 'One world, rival theories' Foreign Policy, 145, 52-62 
Sterling-Folker, Jennifer (2000) 'Competing Paradigms or Birds of a Feather? Constructivism and Neoliberal Institutionalism Compared', International Studies Quarterly, 44: 1, 97-119

Toksöz, Fikret (2004) 'Türk-Yunan belediyeleri arası ilişkiler' in T. Ulaş Belge (eds). Geleceğin sesi: Türk-Yunan Yurttaş Diyaloğu. (İstanbul: İstanbul Bilgi Universitesi)

The Economist (2017) 'Why Turkey and Greece cannot reconcile', The Economist Explains, 14 December, <https://www.economist.com/blogs/economist- explains/ 2017/12/economist-explains-8> accessed 10 April 2018

Thies, Cameron and Timothy M. Peterson (2015) Intra-Industry Trade: Cooperation and Conflict in the Global Political Economy (Stanford California: Stanford University Press)

Triantaphyllou, Dimitrios (2017) 'Greek-Turkish relations and the perceptions of their elites', Blog Post, LSE Blogs, <http:/ /blogs.lse.ac.uk/greeceatlse/2017/01/31/greekturkish- relations-and-the-perceptions-of-their-elites/> accessed 10 April 2018

Tsakonas, Panayotis (2010) The incomplete breakthrough in Greek-Turkish relations: grasping Greece's socialization strategy (New York: Palgrave Macmillan)

Tsarouhas, Dimitris (2009) 'The political economy of Greek-Turkish relations', Southeast European and Black Sea Studies, 9: 1-2, 39-57.

Tzimitras, Harry G (2009) 'Europe, Nationalism and Turkish Greek Aegean disputes' in Othon Anastasakis, Kalypso Nicolaidis and Kerem Öktem (eds) In the long shadow of Europe: Greeks and Turks in the era of postnationalism (Lieden: Brill Press)

Usta, Nazlı (2012) 'Türk-Yunan ekonomik ilişkileri (1980-2010)', (Master Thesis, Yıldız Teknik Universitesi Sosyal Bilimler Enstitüsü)

Vesterbye, Samual D and M Sait Akman (2017) 'A modernized EU-Turkey customs union', European Neighbourhood Council Perspectives, <https://think- asia.org/ handle/11540/6921>, accessed 3 April 2018

Volkan, Vamik D and Norman Itzkowitz (1994) Turks and Greeks: neighbours in conflict (Huntingdon: The Eothen Press)

Walker, Thomas C. and David L. Rousseau (2016) 'Liberalism: a theoratical and empirical assessment' in Myriam Dunn Cavelty and Thierry Balzacq (eds) Routledge handbook of security studies (Abingdon: Routledge)

Waltz, Kenneth (1970) 'The myth of national interdependence', in Charles P. Kindleberger (eds) The international corporation (Cambridge, MA: MIT)

\section{Appendix}

\section{Interviews}

Interview 1: Turkish diplomat at Turkish Consulate General in Athens, 28 July 2015.

Interview 2: Counsellor to Turkish Embassy in Athens, 28 July 2015.

Interview 3: First Secretary to Turkish Embassy in Athens, 28 July 2015.

Interview 4: Advisor from SEV, 29 July 2015.

Interview 5: General Manager of Visit Aegean tourism firm, 30 July 2015.

Interview 6: Trade Counsellor to Turkish Embassy in Athens, 31 July 2015

Interview 7: Deputy Mayor for Tourism and International Relations of Thessaloniki, 18 August 2015.

Interview 8: President of Turkish-Greek Business Council, 13 October 2015.

Interview 9: Investment Portfolio Department Manager, Enterprise Greece ,

1 February 2016.

Interview 10: Former ambassador and former head of the Department of

Greek-Turkish Relations at the Greek Ministry of Foreign Affairs, 16 February 2016.

Interview 11: Chair of Izmir Chamber of Commerce, 3 May 2016. 